Constitutional Logic of Affirmative

Action, which may be published posthumously; and he was beginning a new project, "The Least Dangerous Myth: A Critique of Legal Realism and the Politicization of the Supreme Court Since 1969." Ron received praise from Anthony Lewis in The New York Times for his article, "Studying The Brethren: The Legal-Realist Bias of Investigative Journalism," 1984 American Bar Foundation Research Journal 487. He also received a Harvard Law School Liberal Arts Fellowship in 1987-88.

Ron taught at Skidmore College for ten years. He was a devoted teacher and a highly respected colleague. His courses were always in demand, and he was much respected and loved by his students. Ron was very active in the college community. He developed several courses on constitutional politics and jurisprudence and established an interdisciplinary Law and Society program. At the college memorial service, the chair of the political science department, Mary Ellen Fischer, said:

In contemplating Ron's short life, we cannot help but feel grief and frustration at its premature end. Nevertheless we must recognize that in his years in the Peace Corps, and in his teaching at Wisconsin and Skidmore, he probably touched more human beings in a positive way than most individuals are able to do in a much longer lifetime. We shall miss him sorely as teacher, colleague, and friend, and yet we know that our own lives and the entire college have been enriched by his presence here.

Skidmore College has established an endowed annual lectureship, the Ronald J. Fiscus Lecture in Law and Society.

Ron's academic talents distinguished him in graduate school and in his all-too-short career as a teacher and scholar. His personal warmth and sense of humor enhanced his capacity to translate professional bodies of knowledge about justice and fairness into meaningful everyday practices.

Joel B. Grossman

University of Wisconsin-Madison

Christine B. Harrington

New York University

\section{Robert Younger Fluno}

Robert Fluno, a long-time member of and friend to the American Political Science Association, died October 6, 1990, in Berkeley, California. He was 73 years old.

Bob was born November 27, 1916, in Appleton, Wisconsin. In 1938, he earned a bachelor of arts degree from Rollins College at Winter Park, Florida. Following two years of graduate study at American University, his academic life was interrupted by World War II. Bob served in the United States Naval Reserve, where he held the positions of Communications Officer and Executive Officer. Returning to civilian life in 1946 , he attended the University of Minnesota until 1948 and the London School of Economics and Political Science from 1950-51, earning his doctorate of philosophy in 1952 from the University of Minnesota.

After two years' service as an instructor in political science at the University of Minnesota, Bob accepted a position as an assistant professor of political science at Mount Union College in Alliance, Ohio, in 1948. In 1952, he moved to Whitman College in Walla Walla, Washington. Appointed at the rank of associate professor, he was promoted to full professor status in 1956. The following year he was awarded a Fulbright Scholarship that enabled him to serve as a lecturer at Rajshahi University in Pakistan. In 1960, he was additionally honored by an appointment as Miles C. Moore Professor of Political Science, a title he held until his retirement in 1982.

Bob's contributions to the department of political science, and to Whitman College, were exemplary. During his 30-year appointment, he served as chair of the department; chair of the social science division; pre-law advisor; organizer of the Whitman Political Union, a campus organization in existence for about 25 years; director of ten annual Roots of Contemporary Democracy seminars; and coordinator of numerous extra-curricular programs in political education, including mock political conventions.

In 1977 , on the occasion of his 25 th year as a Whitman faculty member, he was honored with a res- olution issued by the Board of Trustees and Board of Overseers: " $A$ dedicated teacher, a sound scholar, he is the possessor of those rare abilities that combine to make the truly fine teacher who is the glory of a good college. He has been a vital force in the continuing strength of Whitman College." Additional recognition came in 1979 when he received the annual Town-Gown Award, presented to a Whitman faculty or staff member involved in campus and community activities. Finally, in 1982, a group of his former students joined forces to establish the Robert Y. Fluno Award, which is given annually during Whitman commencement ceremonies to the author of the outstanding student paper in the field of political science.

Among Whitman alumni, Bob is best remembered for his courses in American government and democratic theory, but especially for his demanding and stimulating course in constitutional law. That course gave generations of students outstanding preparation for their later work in graduate schools, law programs, and in positions of professional and public service. His "Constitutional Law in a Liberal Arts Curriculum," published in the fall 1953 issue of Legal Education, can still be read with profit by those interested in exploring effective ways to teach legal matters to undergraduates.

Bob's contributions to the field of political science were equally noteworthy. His dissertation concerned Parliamentary control of British nationalized industries. In addition to periodical articles and numerous book reviews, he published with Chester Maxey a revised version of The American Problem of Government in 1957. In 1971, his The Democratic Community was published by Dodd, Mead, and Company. In that work's preface, Bob explained his purpose: "It may be fruitful, as we meet the great challenges of our day, to have reexamined democracy in terms of the earth-bound realities of its actual operating processes, while, in the same breath, stressing the quite proper ambition of all democrats to achieve the high aims of individual freedom and communal participation. Such broad goals deserve to retain their glamour and 
will do so if we admit their inherent ambiguity, viewing them somewhat in the manner that we have learned to view love-as something our inability to describe does not tarnish." Besides indicating the sort of contribution this work makes to the literature of contemporary political theory, these words testify to the spirit of a man whose temperament, mirroring his intellectual convictions, was democratic to the core.

A long-standing member of the American Political Science Association, Bob was also an active participant in the American Academy of Political and Social Science, the American Association of University Professors, and the Western Political Science Association. Moreover, he served as vice president from 1958-59 and president from 1970-71 of the Pacific Northwest Political Science Association.

Bob married artist and poet Ruth Fluno on January 18, 1944. She died November 24, 1974. He was remarried to Marcella Kerins on February 17, 1979 in Walla Walla. Survivors include Marcella; his sister, Helen Jean Rodrigues-Torrent of Clearwater, Florida; a brother, John Fluno of Winter Park; three nieces; and one nephew.

Memorial contributions may be made to the Robert Y. Fluno Award Endowment at Whitman College.

Graeme Auton

Redlands University

Timothy V. Kaufman-Osborn

Whitman College

\section{John H. E. Fried}

John H. E. Fried, a member of the American Political Science Association for some 50 years, died on December 18 , at the age of 85 , after a brief illness.

Born and educated in Vienna, John had a distinguished career as a teacher and practitioner of international law and as an activist in the cause of peace and world order. At the end of World War II he served as special counsel to the United States War Crimes Tribunal, following which he edited the 14-volume record of the 12 trials. John worked in various capacities for the United Nations and was selected as an ar- bitrator in a number of international disputes. He taught international law at the graduate center of the City University of New York and at Lehman College, where he was professor emeritus of political science at the time of his death.

An indefatigable lecturer and writer, John made numerous contributions to the literature of international law. His early association with Nuremberg and the other war crimes trials helped to focus and define his interests for the balance of his life. John's commitment to the theories of crimes against the peace, war crimes and crimes against humanity were the underpinnings of his active opposition to the Vietnam war and the use and threat of use of nuclear weapons. As one of the last survivors of the band of "Nuremberg jurists," John felt a special responsibility to keep the Nuremberg idea alive. But he made many other important contributions to the thinking of his colleagues, including his advocacy of the right to peace as a crucial, "third generation" human right. He was honored at a testimonial party in December 1989 by the Lawyers' Committee on Nuclear Policy and by then Manhattan Borough President David N. Dinkins, who declared December 14 as "John H. E. Fried and the Right to Peace Day" in Manhattan.

John gave unstintingly, not only of his ideas, but also of his time, his interest, and his encouragement to students and colleagues alike. If more international lawyers acted as courageously as John did on the principles they espouse, and if more peace activists took international law as seriously, the world would be a better place.

Peter Weiss

Lawyers' Committee on

Nuclear Policy

\section{Victor Adeola Olorunsola}

On September 29, 1990, the profession lost a noted African scholar. Victor A. Olorunsola died after a long battle with cancer.

Born in Nigeria, Victor completed his undergraduate studies at Friends University with high honors. After completing his master's and doctoral degrees at Indiana University, he taught in the department of political science at California State University, Long Beach, before moving to Iowa State University. During his 20 years at Iowa State, Victor gained an international reputation for his expertise on African politics and on the politics of ethnicity. His major works included The Politics of Cultural Sub-Nationalism in Africa (1972), Societal Reconstruction in Two African States (1977), Soldiers and Power (1977), and State Versus Ethnic Claims: An African Policy Dilemma (1983). He was awarded numerous grants from the Social Science Research Council, the Ford Foundation, the Hoover Institution, the Rockefeller Foundation, and the Rothchild Foundation. In 1981, he organized the Rockefeller Bellagio Conference on State Coherence and Ethnicity.

Victor also developed a reputation as a devoted teacher and a supportive colleague. As chairperson of the department of political science for ten years, Victor built the Ph.D. program. He chaired the University's Departmental Executive Officers Council, coordinated Graduate Studies, and served on a wide range of committees including the Presidential Search Committee, the University Performing Arts Council, the University Committee on the World Food Institute, the College Committee on International Programs, the Truman Fellowship Committee, and the ISU-USAID Zambia Project Advisory Committee. At the national level, Victor served as a member of the Executive Council of the American Political Science Association and as a member of the Board of Directors and the Executive Committee of the African Studies Association. He served for many years as an evaluator of proposals and fellowship applications for the National Science Foundation.

In 1987, Victor became Dean of the College of Arts and Sciences at the University of Louisville. During his administration he restructured the Arts and Sciences Advising Center, introduced an orientation course to facilitate the matriculation of Arts and Sciences undergraduate students, enhanced the college honors program, funded lecture series in 